\title{
Effect of Treatment of Hepatitis C by Directly Acting Antivirals (DAA) on Chronic Hepatitis C, B Coinfected Patients
}

\author{
Afify F.A. Ahmed; Neveen G. Elantouny; Amal A. Zidan* and Mohamed M.H. El Rasad* \\ Internal Medicine and Clinical Pathology* Departments, Faculty of Medicine, Zagazig University \\ *Correspondence author: Mohamed M.H. El Rasad; Mobile: (+20) 01007099510
}

\begin{abstract}
Background: Persons with hepatitis C virus (HCV) who are co-infected with hepatitis B virus (HBV) may be at risk for reactivation of $\mathrm{HBV}$ infection during or following $\mathrm{HCV}$ treatment. $\mathrm{HBV}$ and $\mathrm{HCV}$ share similar modes of transmission, and co-infection with the two viruses does occur.

Objectives: This study aimed to evaluate the effect of HCV anti-viral treatment (DAAS) on HBV in HCV and HBV Coinfected patients.

Patients and methods: The study was performed in Internal Medicine Department (Outpatient Clinic and the Inpatient Ward), Mahalla Hepatology Teaching Hospital, Gharbia, Egypt during the period from August 2016 to November 2017 on $20 \mathrm{HCV}$ and HBV co-infected patients ranged from 18-70 years old.

Results: The age of patients ranging from 26 to 65 years old (median 44). Male represent $55 \%$ and female represent $45 \%$ which showed male predominance. Patients were treated by different types by Hcv antiviral treatment (DAAS) like $(\mathrm{SOF}+\mathrm{DAC}),(\mathrm{SOF}+\mathrm{SIM}),(\mathrm{SOF}+\mathrm{DAC}+\mathrm{RBV})$. At baseline, 12 patients had detectable HBV viral load, 5 Patients had positive (HBsAg) and undetectable HBV viral load and 3 patients had negative (HBsAg) and undetectable HBV viral load. Total number of HBV reactivated cases were 12 patients, 3 of them reactivated by increasing HBV DNA, and 5 of them reactivated by both increasing HBVDNA and ALT flare.

Conclusion: HBV reactivation is a severe, life-threatening consequence of chemotherapy and immunotherapy in patients with chronic hepatitis B infection. Reactivation may be associated with DAA therapy in patients with $\mathrm{HCV} / \mathrm{HBV}$ co-infection. HBV reactivation can be prevented through the use of pretreatment screening and anti-HBV prophylactic treatment.
\end{abstract}

Keywords: Hepatitis C, direct acting antiviral, chronic hepatitis C, chronic hepatitis B.

\section{INTRODUCTION}

Viral hepatitis is a global health problem affecting hundreds of millions of people worldwide. An estimated 1.45 million people die annually from all types of viral hepatitis, mostly from liver disease and cancer caused by these infections. Every day, thousands of people are newly infected because they lack access to information and services for prevention and treatment. Many of these people are unaware of their infection until diagnosed and have the potential to transmit the viruses to others. This year, WHO and its partners are urging policy-makers, health workers and the public to take action to prevent infection and death from hepatitis ${ }^{(\mathbf{1})}$.

Egypt was chosen to host World Hepatitis Day 2015 as the country has demonstrated a high level of commitment by tackling hepatitis comprehensively in their plan of action for prevention, care and treatment 2014-2018 (1).

The Ministry of Health has set up 32 specialized centres and introduced a new hepatitis $\mathrm{C}$ drug last year, which is the first highly-effective and approved directacting antiviral drug for the nationwide treatment of hepatitis $\mathrm{C}$ infection. This medication is safer than previous medications and has been shown to cure more than $90 \%$ of those completing treatment in combination with other drugs. "Viral hepatitis has long been neglected; yet hepatitis $\mathrm{B}$ and $\mathrm{C}$ are preventable, hepatitis B is manageable and hepatitis $\mathrm{C}$ is curable. People are unnecessarily suffering and we are unnecessarily losing lives. This suffering and loss of life should stop," said WHO Regional Director Dr Ala Alwan (2). Before beginning direct-acting antiviral treatment for hepatitis $\mathrm{C}$ virus (HCV) infection, patients should be screened for hepatitis B virus (HBV) infection, according to an updated guideline from the American Association for the Study of Liver Diseases and the Infectious Diseases Society of America ${ }^{(2)}$.

Patients with low or undetectable levels of HBV who do not meet the criteria for HBV treatment should be carefully monitored during direct-acting antiviral treatment for co-occurring $\mathrm{HCV}$, the guideline recommends that some patients have developed very serious illness as a result of reactivation, so vigilance is critical.

Co-infection with $\mathrm{HBV}$ and $\mathrm{HCV}$ is a fairly frequent occurrence, particularly in areas where the two viruses are endemic and among subjects with a high risk of parenteral infections ${ }^{(3)}$.

The clinical relevance of $\mathrm{HBV} / \mathrm{HCV}$ coinfection for disease severity and adverse outcomes, as well as for selection of treatment options is important although information concerning many aspects of dual infection remains largely incomplete. Accumulating evidence suggest that co-infection by HBV and HCV is heterogeneous with respect to varying states of replication for each virus and profiles of immunity ${ }^{(4)}$.

Laboratory evaluation for all possible viral causes including HBV and HCV should be arranged in patients presenting with acute hepatitis. Acute hepatitis can result from simultaneous infection by the two viruses. In addition, for cases of $\mathrm{CHB}$ or $\mathrm{CHC}$ 
ejhm.journals.ekb.eg

infection that present with acute exacerbation, the possibility of superinfection by other viruses should be considered, particularly if the above-mentioned risk factors are noted ${ }^{(4)}$. In addition, silent or occult HBV infection can be found in some patients with $\mathrm{CHC}$ infection ${ }^{(5)}$.

This state of co-infection will not be appreciated if only HBsAg has been checked and confirmatory tests, such as HBV DNA testing by polymerase chain reaction (PCR) should also be arranged when clinically indicated ${ }^{(5)}$.

The aim of this study is to investigate the risk of $\mathrm{HBV}$ reactivation during $\mathrm{HCV}$ antiviral treatment (DAAS) in co-infected HCV and HBV patients.

\section{PATIENTS AND METHODS}

This is a prospective cross sectional study, which was conducted to estimate the effect of anti viral treatment (DAAS) on HBV in co-infected patients in Internal Medicine Department (Outpatient Clinic and the Inpatient Ward), Mahalla Hepatology Teaching Hospital , Gharbia, Egypt during the period from August 2016 to November 2017.

Patients:

$20 \mathrm{HCV}$ and HBV co-infected patients. All patients gave written informed consent to participate in the study.

Ethical approval and written informed consent: An approval of the study was obtained from AlAzhar University academic and ethical committee. Every patient signed an informed written consent for acceptance of the operation.

\section{Inclusion criteria:}

- Chronic HCV and HBV co-infected patients

- Both sexes will be included.

- Age:18-70 years

Exclusion criteria:

- Patients with HIV, or any other active viral infection,

- Autoimmune diseases such as systemic lupus erythematosus (SLE).

- Patients with hematological disorders.

- Cancer patients including hepatocellular carcinoma (HCC).

\section{Methods:}

Between August 2016 and November 2017, 20 patients who received IFN-free DAAs for HCV were consecutively enrolled at the Mahalla Hepatology Teaching Hospital. All patients were aged $\geq 18$ years and had chronic HCV infection, defined as detectable $\mathrm{HCV}$ antibody and serum $\mathrm{HCV}$ ribonucleic acid (RNA) for more than 6 months. Among these patients HBV infection was detected and diagnosed by serum $\mathrm{HBsAg}, \mathrm{HBcAb}$ and serum HBV DNA. In addition, all patients received treatment for 12 weeks and off- therapy follow-up for an additional 12 weeks according to label recommendations.

The patients were subjected to:

- Full history taking and complete physical examination.

- Laboratory investigations including:

- $\quad$ international normalized ratio (INR),

- serum albumin,

- $\quad$ serum bilirubin,

- $\quad$ serum ALT,

- anti-HCV,

- $\quad$ HBsAg,

- $\quad$ anti-HBc,

- HCV RNA,

- $\quad$ HBV deoxyribonucleic acid [DNA].

These investigation were assessed before IFNfree DAAS Treatment.

- Ultrasonography examination for all patients.

- Degree of liver fibrosis was assessed by APRI SCORE.

After 4 weeks, investigations included:

- ALT, AST

- HBsAg,

- HBV DNA,

- HCV RNA

- Bilirubin.

After 12 weeks, investigations included:

- ALT, AST,

- HBsAg,

- HBV DNA,

- HCV RNA,

- Bilirubin.

Furthermore, we evaluated low-level HBV rebound. Patients received oral entecavir or tenofovir disoproxilfumarate therapy if they developed HBVrelated ALT flare and/or hepatic decompensation during the study.

The risk of HBV reactivation, HBV-related ALT flare and HBV-related hepatic decompensation were evaluated for all patients who completed 12 weeks of IFN-free DAAs. For patients who had completed offtherapy follow-up for 12 weeks, the risk of off-therapy $\mathrm{HBV}$ reactivation and the related clinical events were also evaluated.

\section{Statistical analysis:}

Data were analyzed using Statistical Program for Social Sciences (SPSS 17.0; SPSS Inc., Chicago, IL). Patients characteristics were expressed as mean (standard deviation) and percentage when appropriate. The events related to HBV reactivation, ALT flare, hepatic decompensation and HBsAg seroreversion were shown in numbers and percentages with $95 \%$ 
confidence interval (CI) and were compared by $\chi 2$ with Fisher's exact test when appropriate.

All statistical tests were 2-tailed, and the results were statistically significant when a $P$ value was $<0.05$.

\section{RESULTS}

Age was $44.25 \pm 11.19$ with minimum 26 and maximum 65 years old. Males represent $55 \%$ and females represent $45 \%$ (table 1 ).

Figure (1) showed types of different regimens of $\mathrm{HCV}$ treatment (DAAS) taken by co-infected HCV and HBV patients.

All the 20 patients were positive anti-HBC (table 2).

Table (3) showed that 4 patients had negative (HBsAg), one of them had detectable HBV viral load (occult HBV).

Before treatment ALT baseline was $25.80 \pm 6.44$ with minimum 13 and maximum 37. One month after treatment ALT was $36.95 \pm 12.46$ with minimum 22 and maximum 63. 3 months after treatment ALT was $48.90 \pm 27.08$ with minimum 22 and maximum 111 (table 4).

Before treatment AST baseline was $24.65 \pm 6.66$ with minimum 13 and maximum 38. One month after treatment AST was $33.70 \pm 9.30$ with minimum 22 and maximum 55. 3 months after treatment ALT was 39.30 \pm 21.87 with minimum 19 and maximum 101 (table 5).

Before treatment HBVDNA was $2394.9 \pm$ 3618.9 with maximum 12000 and minimum 29. After one month was $1435.0 \pm 2254.2$ with maximum 7500 and minimum 90. After 3 months was $3992.7 \pm 6034.5$ with maximum 21500 and minimum 90 . At baseline, 12 patients had detectable HBV viral load, 5 Patients had positive (HBsAg) and undetectable $\mathrm{HBV}$ viral load, 3 patients had negative (HBsAg) and undetectable HBV viral load (table 6).
Table (1): Distribution of the studied cases according to demographic data $(\mathrm{n}=20)$

\begin{tabular}{|l|c|c|}
\hline & No. & $\%$ \\
\hline Age (years) & \multicolumn{2}{|c|}{} \\
$<40$ & 8 & 40.0 \\
$\geq 40$ & 12 & 60.0 \\
\hline Min. - Max. & \multicolumn{2}{|c|}{$26.0-65.0$} \\
Mean + SD. & \multicolumn{2}{|c|}{$44.25 \pm 11.19$} \\
Median & \multicolumn{2}{|c|}{} \\
Sex & 11 & 55.0 \\
Male & 9 & 45.0 \\
Female & 9 \\
\hline
\end{tabular}

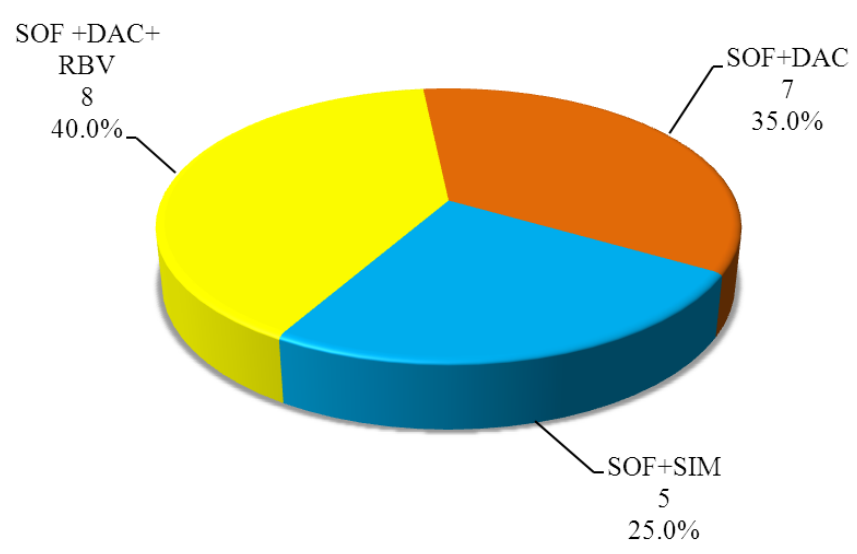

Figure (1): Distribution of the studied cases according to type of treatment $(n=20)$

Table (2): Distribution of the studied cases according to Anti-HBC $(\mathrm{n}=20)$

\begin{tabular}{||l|c|c|}
\hline Anti-HBC & No. & \% \\
\hline Negative & 0 & 0.0 \\
Positive & 20 & 100.0 \\
\hline
\end{tabular}

Table (3): Comparison between the different periods according to HBsAg $(n=20)$

\begin{tabular}{|c|c|c|c|c|c|c|c|c|}
\hline \multirow{3}{*}{ HBsAg } & \multirow{2}{*}{\multicolumn{2}{|c|}{ Before treatment }} & \multicolumn{4}{|c|}{ After treatment } & \multirow{3}{*}{$\square^{2}$} & \multirow{3}{*}{$\mathbf{p}$} \\
\hline & & & \multicolumn{2}{|c|}{$\begin{array}{l}\text { Pne month with } \\
\text { DAAS }\end{array}$} & \multicolumn{2}{|c|}{$\begin{array}{c}\text { After } 3 \text { month } \\
\text { with DAAS }\end{array}$} & & \\
\hline & No. & $\%$ & No. & $\%$ & No. & $\%$ & & \\
\hline $\begin{array}{l}\text { Negative } \\
\text { Positive }\end{array}$ & $\begin{array}{c}4 \\
16\end{array}$ & $\begin{array}{l}20.0 \\
80.0\end{array}$ & $\begin{array}{c}4 \\
16\end{array}$ & $\begin{array}{l}20.0 \\
80.0\end{array}$ & $\begin{array}{c}4 \\
16\end{array}$ & $\begin{array}{l}20.0 \\
80.0\end{array}$ & 0.116 & 1.000 \\
\hline
\end{tabular}

Table (4): Comparison between the different periods according to ALT $(n=20)$

\begin{tabular}{|c|c|c|c|c|c|}
\hline \multirow[b]{2}{*}{ ALT } & \multirow[b]{2}{*}{ Before treatment } & \multicolumn{2}{|c|}{ After treatment } & \multirow[b]{2}{*}{${ }^{\mathrm{Fr}} \chi^{2}$} & \multirow[b]{2}{*}{$\mathbf{p}$} \\
\hline & & $\begin{array}{c}\text { One month with } \\
\text { DAAS }\end{array}$ & $\begin{array}{c}\text { Ifter } 3 \text { month with } \\
\text { DAAS }\end{array}$ & & \\
\hline $\begin{array}{l}\text { Min. - Max. } \\
\text { Mean } \pm \text { SD. } \\
\text { Median } \\
\end{array}$ & $\begin{array}{c}13.0-37.0 \\
25.80 \pm 6.44 \\
25.50 \\
\end{array}$ & \begin{tabular}{|c|}
$22.0-63.0$ \\
$36.95 \pm 12.46$ \\
33.0 \\
\end{tabular} & \begin{tabular}{|c|}
$22.0-111.0$ \\
$48.90 \pm 27.08$ \\
38.0 \\
\end{tabular} & $14.608^{*}$ & $0.001^{*}$ \\
\hline Sig. bet. periods. & \multicolumn{3}{|c|}{$\mathrm{p}_{1}=0.006^{*}, \mathrm{p}_{2}<0.001^{*}, \mathrm{p}_{3}=0.385$} & & \\
\hline
\end{tabular}

${ }^{\mathrm{Fr}} \chi^{2}$ : Chi square for Friedman test, Sig. bet. periods was done using Post Hoc Test (Dunn's -Bonferroni)

$\mathrm{p}_{1}$ : $\mathrm{p}$ value for comparing between before and after one month with DAAS 
ejhm.journals.ekb.eg

$\mathrm{p}_{2}: \mathrm{p}$ value for comparing between before and after 3 month with DAAS

$\mathrm{p}_{3}$ : $\mathrm{p}$ value for comparing between after one month with DAAS and after 3 month with DAAS

*: Statistically significant at $\mathrm{p} \leq 0.05$.

Table (5): Comparison between the different periods according to AST $(n=20)$

\begin{tabular}{|c|c|c|c|c|c|}
\hline \multirow[b]{2}{*}{ AST } & \multirow[b]{2}{*}{ efore treatment } & \multicolumn{2}{|c|}{ After treatment } & \multirow[b]{2}{*}{${ }^{\mathrm{Fr}} \chi^{2}$} & \multirow[b]{2}{*}{$\mathbf{p}$} \\
\hline & & $\begin{array}{l}\text { One month with } \\
\text { DAAS }\end{array}$ & $\begin{array}{c}\text { After } 3 \text { month } \\
\text { with DAAS }\end{array}$ & & \\
\hline $\begin{array}{l}\text { in. - Max. } \\
\text { ean } \pm \text { SD. } \\
\text { edian }\end{array}$ & $\begin{array}{c}13.0-38.0 \\
24.65 \pm 6.66 \\
25.50\end{array}$ & $\begin{array}{c}22.0-55.0 \\
33.70 \pm 9.30 \\
32.50\end{array}$ & $\begin{array}{c}19.0-101.0 \\
39.30 \pm 21.87 \\
33.0\end{array}$ & $10.800^{*}$ & $0.005^{*}$ \\
\hline Sig. bet. periods. & \multicolumn{3}{|c|}{$\mathrm{p}_{1}=0.004^{*} \mathrm{p}_{2}=0.004^{*} \mathrm{p}_{3}=1.000$} & & \\
\hline
\end{tabular}

${ }^{\mathrm{Fr}} \chi^{2}$ : Chi square for Friedman test, Sig. bet. periods was done using Post Hoc Test (Dunn's -Bonferroni)

$\mathrm{p}_{1}$ : $\mathrm{p}$ value for comparing between before and after one month with DAAS

$\mathrm{p}_{2}: \mathrm{p}$ value for comparing between before and after 3 month with DAAS

$\mathrm{p}_{3}: \mathrm{p}$ value for comparing between after one month with DAAS and after 3 month with DAAS

*: Statistically significant at $\mathrm{p} \leq 0.05$

Table (6): Comparison between the different periods according to HBV DNA $(n=20)$

\begin{tabular}{|c|c|c|c|c|c|c|c|c|}
\hline \multirow{3}{*}{ HBV DNA } & \multirow{2}{*}{\multicolumn{2}{|c|}{ Sefore treatment }} & \multicolumn{4}{|c|}{ After treatment } & \multirow{3}{*}{$\begin{array}{l}\text { Test of } \\
\text { Sig. }\end{array}$} & \multirow{3}{*}{$\mathbf{p}$} \\
\hline & & & \multicolumn{2}{|c|}{$\begin{array}{c}\text { One month with } \\
\text { DAAS }\end{array}$} & \multicolumn{2}{|c|}{\begin{tabular}{|c|} 
fter 3 month with \\
DAAS \\
\end{tabular}} & & \\
\hline & No. & $\%$ & No. & $\%$ & No. & $\%$ & & \\
\hline $\begin{array}{l}\text { gative } \\
\text { itive }\end{array}$ & $\begin{array}{c}8 \\
12\end{array}$ & $\begin{array}{l}0.0 \\
0.0\end{array}$ & $\begin{array}{c}6 \\
14\end{array}$ & $\begin{array}{l}30.0 \\
70.0\end{array}$ & $\begin{array}{c}4 \\
16\end{array}$ & $\begin{array}{l}20.0 \\
80.0\end{array}$ & $\begin{array}{l}\chi^{2}= \\
1.905\end{array}$ & 0.386 \\
\hline $\begin{array}{l}\text { n. - Max. } \\
\text { an } \pm \text { SD. } \\
\text { dian }\end{array}$ & \multicolumn{2}{|c|}{$\begin{array}{c}29.0-12000.0 \\
2394.9 \pm 3618.9 \\
875.0\end{array}$} & \multicolumn{2}{|c|}{$\begin{array}{c}90.0-7500.0 \\
35.0 \pm 2254.2 \\
450.0\end{array}$} & \multicolumn{2}{|c|}{$\begin{array}{c}90.0-21500.0 \\
92.7 \pm 6034.5 \\
1550.0\end{array}$} & $\begin{array}{l}{ }_{\mathrm{Fr}} \chi^{2}= \\
3.500\end{array}$ & 0.174 \\
\hline
\end{tabular}

\section{DISCUSSION}

The recent introduction of direct-acting antiviral drugs (DAAs) for treatment of the hepatitis $\mathrm{C}$ virus $(\mathrm{HCV})$ has greatly improved the management of $\mathrm{HCV}$ for infected patients. These viral protein inhibitors act rapidly, allowing $\mathrm{HCV}$ clearance and increasing the sustained virological response rates ${ }^{(3)}$.

However, hepatitis B virus (HBV) reactivation has been reported in HCV/ HBV co-infected patients. Hepatitis $B$ reactivation refers to an abrupt increase in the HBV and is well documented in patients with previously undetected HBV DNA due to inactive or resolved HBV infection ${ }^{(4)}$.

Reactivation can occur spontaneously, but in most cases, it is triggered by various factors. Reactivation can be transient, without clinical symptoms; however, it usually causes a hepatitis flare. $\mathrm{HBV}$ reactivation may occur regardless of $\mathrm{HCV}$ genotype and type of DAA regimen ${ }^{(6)}$.

HBV screening is strongly recommended for coinfected $\mathrm{HCV} / \mathrm{HBV}$ patients before initiation and during DAA therapy regardless of HBV status, HCV genotype and class of DAAs used. HBV reactivation can be prevented with pretreatment screening and prophylactic treatment when necessary.

The aim of this study was to evaluate the effect of $\mathrm{HCV}$ antiviral treatment (DAAS) on HBV in co-infected HCV and HBV Patients.
In this work, the age of patients ranged from 26 to 65 years old (median 44). This reflect that patients were infected during their active phases of life being subjected to the different risk factors of HCV infection. This result is comparable with that of Ende et al. ${ }^{(6)}$.

Regarding sex distribution among studied group, male represented 55\% and female represented $45 \%$, which showed the predominance in male. This male predominance highlighted the high exposure rate and the percentage of adult males seeking medical advice. A similar male predominance was reported by Ende $\boldsymbol{e t} \boldsymbol{a l}$. (6). These results probably disclare the characteristics of the blood donor population who are presumably healthy adult males who seek medical assistance after being diagnosed in blood banks.

In this work, patients were treated by different types by $\mathrm{HCV}$ antiviral treatment (DAAS) like (SOF + $\mathrm{DAC}),(\mathrm{SOF}+\mathrm{SIM}),(\mathrm{SOF}+\mathrm{DAC}+\mathrm{RBV})$.

This results are consistent with previous studies that reported the clinical characteristics of the patients vary as receiving different types of oral DAAS ${ }^{(7)}$.

Our study included 4 patients had negative (HBsAg). One of them had detectable viral load (occult HBV).

At baseline, 12 patients had detectable HBV viral load, 5 Patients had positive (HBsAg) and undetectable HBV viral load, 3 patients had negative 
(HBsAg) and undetectable HBV viral load. This result agree with Chen et al. ${ }^{(8)}$.

As regard ALT level monitoring in different time among studied patients, we found that before treatment ALT baseline was $25.80 \pm 6.44$ with minimum 13 and maximum 37. One month after treatment ALT was $36.95 \pm 12.46$ with minimum 22 and maximum 63.3 months after treatment ALT was $48.90 \pm 27.08$ with minimum 22 and maximum 111. This result is similar to that reported by Takayama et al. ${ }^{(9)}$.

As regard AST, before treatment AST baseline was $24.65 \pm 6.66$ with minimum 13 and maximum 38 . One month after treatment ALT was $33.70 \pm 9.30$ with minimum 22 and maximum 55. 3 months after treatment ALT was $39.30 \pm 21.87$ with minimum 19 and maximum 101. As regard HBVDNA Before treatment HBVDNA was $2394.9 \pm 3618.9$ with maximum 12000 and minimum 29. After one month was $1435.0 \pm 2254.2$ with maximum 7500 and minimum 90. After 3 months was $3992.7 \pm 6034.5$ with maximum 21500 and minimum 90. This is in agreement with Collins et al. ${ }^{(\mathbf{1 0})}$.

In our study, it was found that total number of HBV Reactivated cases were 12 patients, 3 of them reactivated by increasing HBV DNA and 5 of them reactivated by both increasing HBVDNA and ALT flare. As regard patients reactivated by HBV DNA, it was found that one patient below 40 years old and 2 above $4 \mathrm{o}$ years old, all were males, 2 of them received $(\mathrm{SOF}+\mathrm{DAC}+\mathrm{RBV})$ and one of them received (SOF + SIM ) as HCV antiviral treatment, all were positive anti $\mathrm{HBC}, 2$ were positive $\mathrm{HBsAg}$ and one negative HBsAg, 2 of them were negative HBV DNA, one was positive HBVDNA before start of $\mathrm{HCV}$ anti-viral treatment. This result agrees with Demonte et al. ${ }^{(11)}$

Regarding patients that reactivated by increasing HBVDNA and ALT flare, it was found that 3 of them were females and 2 were males, 3 below 40 years old and 2 above 40 years old, one received (SOF + DAC + $\mathrm{RBV}), 2$ received $(\mathrm{SOF}+\mathrm{DAC}), 2$ received $(\mathrm{SOF}+$ SIM), all were positive anti HBC. 4 of them were positive $\mathrm{HBsAg}$. One was negative before beginning of $\mathrm{HCV}$ treatment. Also, 2 cases were negative viremia and 3 cases were positive.This study is compatatible with that of Madonia et al. ${ }^{(12)}$.

The ALT ratio in (patients reactivated by DNA only) was 22 with maximum 35 and minimum 21 before start of treatment and was 38 with maximum 38 and minimum 37 after 3 months of treatment. The ALT ratio in (patients reactivated by both DNA and ALT) was 28 with maximum 37 and minimum 13 before start of treatment and was 88 with maximum 111 and minimum 55 after 3 months. This study agrees with Hayashi et al. ${ }^{(13)}$.

\section{CONCLUSION}

Generally, HBV reactivation is a severe, lifethreatening consequence of chemotherapy and immunotherapy in patients with chronic hepatitis B infection. The severity of $\mathrm{HBV}$ reactivation ranges from mild with asymptomatic elevation of aminotransferases to fulminant liver failure.

Recent evidence suggests that reactivation may be associated with DAA therapy in patients with $\mathrm{HCV} / \mathrm{HBV}$ co-infection. HBV screening is recommended for patients both before the initiation and during DAA therapy.

HBV reactivation can be prevented through the use of pretreatment screening and anti-HBV prophylactic treatment. Existing evidence is not enough to support pre-emptive therapy in all patients with HBsAg or occult hepatitis B.

\section{REFERENCES}

1. World Health Organization (2017): http://www.emro.who.int/media/news/world-hepatitis-dayin-egypt-focuses-on-hepatitis-b-and-c-prevention.html.

2. Amer KE, Marwan I (2016): Living donor liver transplantation in Egypt. Hepatobiliary Surg Nutr., 5: 98106.

3. Pontisso P, Ruvoletto MG, Fattovich G et al. (2013): Clinical and virological profiles in patients with multiple hepatitis infections. Gastroenterology, 105: 1529-33.

4. Liaw YF, Chen YC, Sheen IS et al. (2004): Impact of acute hepatitis $\mathrm{C}$ virus super-infection in patients with chronic hepatitis B virus infection. Gastroenterology, 126: 1024-9.

5.Fukuda R, Ishimura $\mathrm{N}$, Niigaki $\mathrm{M}$ et al. (1999): Serologically silent hepatitis B virus co-infection in patients with hepatitis $\mathrm{C}$ virus-associated chronic liver disease: clinical and virological significance. J Med Virol., 58: 2017.

6. Ende AR, Kim NH, Yeh MM et al. (2015): Fulminant hepatitis $\mathrm{B}$ reactivation leading to liver transplantation in a patient with chronic hepatitis $C$ treated with simeprevir and sofosbuvir: a case report. J Med Case Rep., 9: 164-170.

7.Wang C, Ji D, Chen J et al. (2016): Hepatitis due to Reactivation of Hepatitis B Virus in Endemic Areas Among Patients With Hepatitis C Treated With Direct-acting Antiviral Agents. Clin Gastroenterol Hepatol., 5: 3037030376.

8.Chen SL and Morgan TR (2017): The Natural History of Hepatitis C Virus (HCV) Infection". International Journal of Medical Sciences, 3 (2): 47-52.

9.Takayama H, Sato T, Ikedwwa F et al. (2016): Reactivation of hepatitis B virus during interferon-free therapy with daclatasvir and asunaprevir in patient with hepatitis B virus/hepatitis C virus coinfection. Hepatol Res., 46: 489491.

10. Collins JM, Raphael KL, Terry C et al. (2015): Hepatitis B Virus Reactivation During Successful Treatment of Hepatitis C Virus With Sofosbuvir and Simeprevir. Clin Infect Dis., 61: 1304-1306.

11. De Monte A, Courjon J, Anty R et al. (2016): (editors). Fields Virology. Vol. 4. Philadelphia, PA: Lippincott-Raven Publishers. https://www.worldcat.org/title/fieldsvirology/oclc/32512536

12. Madonia S, Orlando E, Madonia G et al. (2017): HCV/HBV coinfection: The dark side of DAAs treatment? Liver Int., 37 (7): 1086-1087.

13. Hayashi K, Ishigami M, Ishizu Y et al. (2016): A case of acute hepatitis B in a chronic hepatitis C patient after daclatasvir and asunaprevir combination therapy: hepatitis B virus reactivation or acute self-limited hepatitis? Clin J Gastroenterol., 9: 252-6. 